\title{
Urban Acupuncture in Large Cities: Filtering Framework to Select Sensitive Urban Spots in Riyadh for Effective Urban Renewal
}

\author{
* Dr. Usama A. Nassar
}

Faculty of Engineering, Suez Canal University, Ismailia, Egypt

College of Engineering, Taibah University, Madinah, Saudi Arabia Email: usama.a.nassar@gmail.com

\begin{tabular}{|l|}
\hline ARTICLE INFO: \\
Article History: \\
Received 25 April 2020 \\
Accepted 7 June 2020 \\
Available online 18 June 2020 \\
\hline Keywords: \\
Urban Acupuncture; \\
Riyadh; \\
Sensitive Spot; \\
Urban Renewal; \\
Human-centered Spaces. \\
\begin{tabular}{|l} 
This article is an open access \\
article distributed under the terms and \\
conditions of the Creative Commons \\
Attribution (CC BY) license \\
(C) (i) \\
access at www.ijcua.com
\end{tabular} \\
\hline
\end{tabular}

\section{ABSTRACT}

New revitalization and regeneration strategies are currently taking place as a scheme for reassessing urban spaces. This paper, as a result, navigates the theory of Urban Acupuncture (UA) as a quick and effective tool that can be adopted in large cities. Using Riyadh city as a case study, it discusses how this tool can be used to achieve maximum results with minimal effort in the most critical places. Riyadh city is the capital of Saudi Arabia and is considered one of the fastest-growing metropolitan cities in the Arab world. Through time, it has transformed into a city with leftover open spaces and an ever-increasing population. The study commences by exploring the term UA and its principles and similarly presents some of its successful international examples. It thereafter delves into the past and current situation in the city to show some of the challenges it faces. The study aims to develop a filtering framework for selecting a suitable sensitive spot that can be used to apply the concept of UA. A conclusion is made that as a small-scale space approach and a progressive concentrated urban renewal strategy.

JOURNAL OF CONTEMPORARY URBAN AFFAIRS (2021), 5(1), 1-18. https://doi.org/10.25034/ijcua.2021.v5n1-1

Copyright (C 2020 Usama A. Nassar www.ijcua.com

\section{Introduction}

Urban areas are currently experiencing rapid population growth rates. It has, therefore, become a necessity to use creative and innovative strategies to cope with the challenges that may occasion from this growth. Considering what the world is currently going through regarding the COVID-19 pandemic, there is a need to pursue strategies that would quickly and efficiently address such emerging challenges (Casagrande, 2020). From the foregoing, the traditional strategic urban development plans whose scope usually

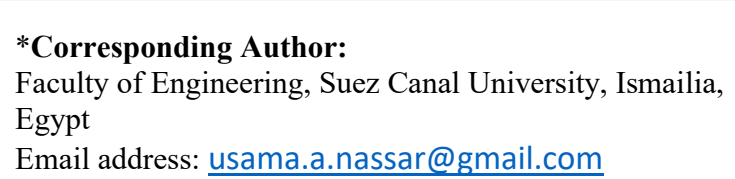

Faculty of Engineering, Suez Canal University, Ismailia, Egypt

Email address: usama.a.nassar@gmail.com 
covers a macro scale might not provide a suitable path for addressing such challenges. This is because there is now a great demand for a much faster approach that may be used to address these challenges at a micro level, consequently creating a healthier environment particularly in the most needed areas (Lastra \& Pojani, 2018). This paper, therefore, seeks to explore the use of UA as an effective and shortest way of promoting urban development in large cities. The intention is to reduce urban inflation in addition to restoring the green environment by dealing with leftover open spaces individually within the urban tissue. It also seeks to develop a comprehensive framework that would facilitate the application of UA as a tool for guiding the selection of the most urgent spots in the city fabric that need to be developed. A literature review is also undertaken to account for the difference between large- and small-scale urban renewal strategies and UA strategy in addition to defining the UA approach with its principles and strategies. The paper further presents the following two international examples drawn from Egypt and Indonesia to demonstrate the different strategies used.

- Upgrading of a slum area in Kampung Jakarta,

Indonesia (Nurdiansyah, 2018).
- Pedestrian Passage in Downtown Cairo, Egypt (Tang et al., 2015). Major Arab cities have experienced a rapid growth rate in recent years which has dramatically changed land use and old urban fabric. Riyadh is one of the cities that has rapidly expanded on account of industrialization and population increase. For instance, in 1862, it had 7500 people (Palgrave, 1868) and was projected in 2010 to reach 6,152,899 (Abderrahman, 2000). The city was for that reason selected to study and extract the filtration framework due to its fast-urban growth rate that is elicited by different development patterns. The study ends by presenting the conclusion and recommendations that cover the following:

- Recommendation on UA approach implementation.

- Future urban development for Riyadh, and how UA can be used with the other urban development strategies.

- Proposed future studies to deal with the ongoing urban issues in cities.

Figure 1 shows the structure of the research. The aim is to reach the desired filtration framework that applies UA theory.

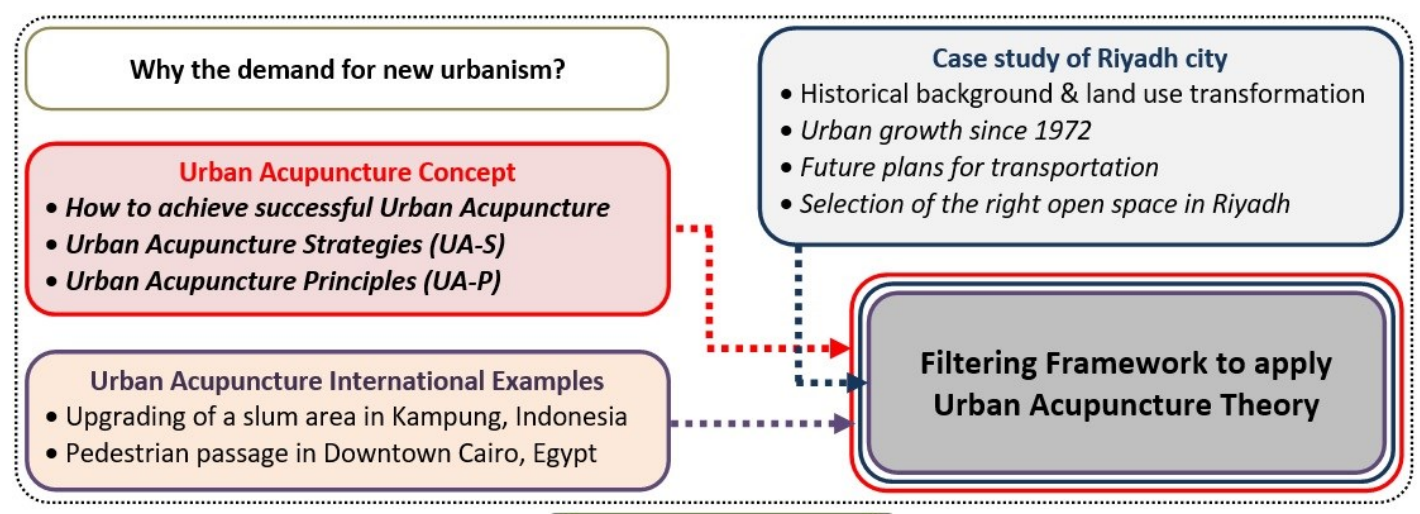

Conclusion and Recommendations

Figure 1. Structure of the research.

\section{Why the Demand for a New Urbanism?}

Several urban planners, such as Christopher Alexander, Allan Jacobs, and Lewis Mumford have stressed the importance of open spaces in urban areas. They highlighted the major contribution of public spaces to quality of life and how it contributes to urban image and economic development (Shidan \& Qian,
$2011)$. The development strategies of public open spaces in the twentieth century were mostly large in scale with an overview vision of all the city, which is not efficient and desirable with the quickly accelerating pace of the surrounding environment (Ellin, 2007).

The demand for a new tool of urbanism started to arise in recent decades. De Meulder stated in his book, Urban Trialogues, that with all the 
fast growth and complexity of cities at the moment, changing development conditions, and dramatic shifts in urban situations in the societies, it seems to be clear that the traditional approach of master planning and static land use distribution is not sufficient to achieve sustainable and comprehensive urban development (De Meulder et al., 2004). In European countries, some plans to develop urban areas were large in scale, and the revitalisation of every neighbourhood was usually made by governments at a local level, which proved to not be a suitable approach compared to pinpointing the local problems of each area (Lastra \& Pojani, 2018). On the other hand, in 2007, the Netherlands had forty neighbourhoods known for having a lot of problems and dysfunctions. The government's approach to solving the problem was to spotlight the potential in each neighbourhood and start separate action plans for development instead of making a general vision (Permentier et al., 2013).

The case of a Seattle neighbourhood in the USA is another model of how the local community found a unique approach for developing opportunities for their urban spaces when the community members built up a small movie theatre to replace an unused car parking laneway (Wolfe, 2011). The evidence above indicates that UA as a new way to deal with open spaces on a smaller scale has been becoming more desirable than a top-to-bottom urban vision. environment as a dynamic accumulative process. A successful city must, therefore, have the ability to understand and interact with the inhabitants to solve its difficulties (Jacobs, 2002). In this approach of understanding, UA has been defined as a kind of surgery performed in a city (Ellin, 2007). The term UA went through various steps from its initial concept, developing through time. The concept was first conceived by the Barcelona urbanist, Manuel de Solà-Morales, as the urgent need to achieve urban development projects in a short period and have the maximum effect on Barcelona city revitalisation in the 1980s (Degen \& Garcia, 2012). The purpose was to develop the city by implementing small urban projects in residential neighbourhoods (Marzi \& Ancona, 2004).

\subsection{Urban Acupuncture vs. other renewal strategies}

UA aims to have an impact on every potential space in the city. It can be applied through art-sometimes, it is called the 'true art of our urban context' (Lerner, 2016). That is why it is different from the large urban renewal strategy that has been previously used; it is a localised, small-scale intervention method. Because this approach should be influenced by the local inhabitants, it must be raised from the smallestscale urban city development (Marzi \& Ancona, 2004; Harjoko, 2009a). Table 1 illustrates the comparison between UA, smalland large-scale urban renewal strategies.

\section{Urban Acupuncture Concept}

Thinking of a city as a living organism is an approach to understanding the urban

Table 1. Comparison between UA, Large and Small-Scale Urban Renewal.

\begin{tabular}{c|c|c|c}
\hline \multirow{2}{*}{ Comparison Items } & \multicolumn{3}{|c}{ Various Types of Urban Renewal } \\
\cline { 2 - 4 } Aim of Development & $\begin{array}{c}\text { Large-Scale Urban } \\
\text { Renewal }\end{array}$ & $\begin{array}{c}\text { Small-Scale Urban } \\
\text { Renewal }\end{array}$ & Urban Acupuncture \\
\hline $\begin{array}{c}\text { Director of } \\
\text { Development }\end{array}$ & $\begin{array}{c}\text { Government and } \\
\text { developers }\end{array}$ & $\begin{array}{c}\text { Government and residents } \\
\text { and living conditions }\end{array}$ & $\begin{array}{c}\text { Golve different urban } \\
\text { problems (social, } \\
\text { environmental, etc.) }\end{array}$ \\
\hline $\begin{array}{c}\text { Government, developers, } \\
\text { and local community } \\
\text { Method }\end{array}$ & $\begin{array}{c}\text { Mostly to demolish and } \\
\text { reconstruct all at one time }\end{array}$ & $\begin{array}{c}\text { Achieve goal in stages } \\
\text { progressively }\end{array}$ & $\begin{array}{c}\text { The accumulative effect, } \\
\text { step by step }\end{array}$ \\
\hline Funding & $\begin{array}{c}\text { One-time investment from } \\
\text { government or developers }\end{array}$ & $\begin{array}{c}\text { From government and } \\
\text { residents' funds }\end{array}$ & $\begin{array}{c}\text { Various/unlimited } \\
\text { channels }\end{array}$ \\
\hline
\end{tabular}


JOURNAL OF CONTEMPORARY URBAN AFFAIRS, 5(1), 1-18/ 2021

\begin{tabular}{|c|c|c|c|}
\hline \multirow[b]{2}{*}{ Comparison Items } & \multicolumn{3}{|c|}{ Various Types of Urban Renewal } \\
\hline & $\begin{array}{c}\text { Large-Scale Urban } \\
\text { Renewal }\end{array}$ & $\begin{array}{c}\text { Small-Scale Urban } \\
\text { Renewal }\end{array}$ & Urban Acupuncture \\
\hline $\begin{array}{c}\text { Strategy: } \\
\text { Planning and design }\end{array}$ & From top to bottom & From top to bottom & From top to bottom \\
\hline $\begin{array}{l}\text { Strategy: } \\
\text { Construction }\end{array}$ & From top to bottom & From bottom to top & From bottom to top \\
\hline $\begin{array}{l}\text { The difficulty of } \\
\text { Strategy Application }\end{array}$ & Simple & Flexible & Flexible \\
\hline $\begin{array}{l}\text { Level of Urban } \\
\text { Development }\end{array}$ & One-time improvement & Step-by-step improvement & Step-by-step improvement \\
\hline $\begin{array}{c}\text { Preserving Local style } \\
\text { and Historical } \\
\text { Context }\end{array}$ & $\begin{array}{c}\text { The small level of } \\
\text { preservation with a large } \\
\text { level of demolition }\end{array}$ & $\begin{array}{c}\text { A small level of } \\
\text { preservation with a small } \\
\text { level of demolition }\end{array}$ & $\begin{array}{c}\text { A balanced level of } \\
\text { preservation }\end{array}$ \\
\hline $\begin{array}{c}\text { Economic Land Use } \\
\text { Benefit }\end{array}$ & High & Low & High \\
\hline $\begin{array}{c}\text { Sustainability and } \\
\text { Ongoing } \\
\text { Development }\end{array}$ & Low & Moderate & High \\
\hline
\end{tabular}

\subsection{How to achieve a successful UA Strategy}

To choose the best successful strategy in UA, two important criteria must be achieved. The first one is the quality and effectiveness of the urban catalyst and mixed-use areas; the second is to choose the best sensitive spot.

\subsubsection{Urban catalyst effectiveness and mixed- use}

The most effective catalyst for UA must be related to ecological, economic, and social factors (Jackson, 2018). From an architectural point of view, any successful building must stimulate economic and social activities and be within walking distance of other activities (Rosa-Jiménez et al., 2017). Hence, it is more effective to select areas with more mixed uses and different types of recreational facilities.

\subsubsection{Selection of the best sensitive spot}

Like the human body, each place in a city has certain linkages to other places. Space most frequently linked with other spots is the most suitable spot for the needle of UA. With this ability, like stem cells in a human body, UA would improve the whole structure of the city (Apostolou, 2015).

UA theory has a more effective impact when applied to human-centred open spaces, where the spaces are more walkable, safe, accessible, and sociable. Thus, it is better to choose this approach for small, leftover, neglected spaces in the urban fabric, not for well-designed, large open spaces or parks. As shown in Table 2, the concept of humanoriented spaces can be categorised as follows:

- Spatial aspects that relate to spatial forms of space.

- Socio-spatial aspects, which involve the relation between users and open space.

Table 2. Different aspects of human-centred public open spaces.

\begin{tabular}{l|l|l}
\multicolumn{1}{c|}{ Aspects } & Explanation \\
\hline \multirow{4}{*}{$\begin{array}{l}\text { Spatial } \\
\text { aspects }\end{array}$} & Walkable & $\begin{array}{l}\text { Enhances pedestrian-friendly activity and ease of } \\
\text { navigation for people walking through (Ewing and Handy, } \\
\text { 2009). }\end{array}$ \\
\cline { 2 - 3 } & Safe & $\begin{array}{l}\text { Offers protection from traffic movement and crime, } \\
\text { increasing the feeling of safety (Gehl and Lars, 2008). }\end{array}$ \\
\cline { 2 - 3 } & Accessible & $\begin{array}{l}\text { Easy to access and move around during all the times of the } \\
\text { day (Varna, 2014; Mehta, 2014). }\end{array}$ \\
\cline { 2 - 3 } & Comfortable & $\begin{array}{l}\text { Offers different kinds of activities to practice, either when } \\
\text { standing or sitting (Casagrande, 2020). }\end{array}$ \\
\cline { 2 - 3 } & Delightful & $\begin{array}{l}\text { Has special elements of aesthetic value in a human-scale } \\
\text { environment (Kamel et al., 2017). }\end{array}$ \\
\hline
\end{tabular}




\begin{tabular}{l|l|l}
\hline \multirow{4}{*}{$\begin{array}{l}\text { Socio- } \\
\text { spatial } \\
\text { aspects }\end{array}$} & Inclusive & $\begin{array}{l}\text { Encourages all types of activities; welcoming and inviting } \\
\text { (Madanipour, 2010). }\end{array}$ \\
\cline { 2 - 3 } & Sociable & $\begin{array}{l}\text { Enhances social-user interaction for both active and passive } \\
\text { types (Carmona et al., 2010). }\end{array}$ \\
\cline { 2 - 3 } & Liveable & $\begin{array}{l}\text { Well used and busy all day long for both day and night } \\
\text { activities (Gehl and Lars, 2008). }\end{array}$ \\
\hline
\end{tabular}

\subsection{Urban Acupuncture Strategies (UA-S)}

From the literature review on UA, the research will draw a conclusion in reference to the strategies that have been used mostly to develop small urban spaces (Messeter, 2015; Apostolou, 2015; Houghton et al., 2015; Lastra \& Pojani, 2018; Casagrande, 2020). The different UA strategies can be listed as follows:

UA-S01 Use existing resources

It is important to recognise each neighbourhood's resources and use them in the best way by utilising direct local citizen participation to achieve this.

UA-S02 Redefinition of aesthetic urban elements

Urban features show the identity of the street, and open-space furniture should connect with the personality of each space individually in an aesthetic way.

UA-S03 Achieve diversity and inclusivity Promote the presence of diversity and establish the connection between residents yet allow each one to express his taste.

UA-S04 Increase visibility of public buildings Stress visually on important public buildings' entrances through different colours and unique vegetation (Rosa-Jiménez et al., 2017).

\section{UA-S05 Open space redefinition}

Understand the vital role that open space plays and increase its potential to form positive events in daily lives.

UA-S06 Reuse and recycling of resources The word "recycling" has become especially important in every contemporary design of open space; it is a step to redefine the space as a living hybrid.

UA-S07 Confirm the sentimental value of vegetation

Improve the relationship between the local citizen and the natural environment; promote diversity in vegetation according to each site's identity.

UA-S08 Connectivity and graduate design Each intervention in this strategy should connect with the open space and work gradually from the highest interest to the edge. UA-S09 Adaptive and open design

The design should be flexible and aim to promote an adaptive and open style; the level of interaction with local citizens will certainly be affected gradually.

UA-S10 Shared management and responsibility Empower local users and the neighbourhood to the extent that management systems of public space must ensure their inputs over time.

\subsection{Urban Acupuncture Principles (UA-P)}

Most studies on UA indicate that no model or rule has applied the approach to the existing open city spaces. Instead, what exists is a group of principles set as a trial for possible use in future studies. Based on the literature review, this research will, therefore, conclude with a set of important principles that can be used to achieve the development of open city spaces through small-scale urban interventions. Figure 2 shows the principles of UA.

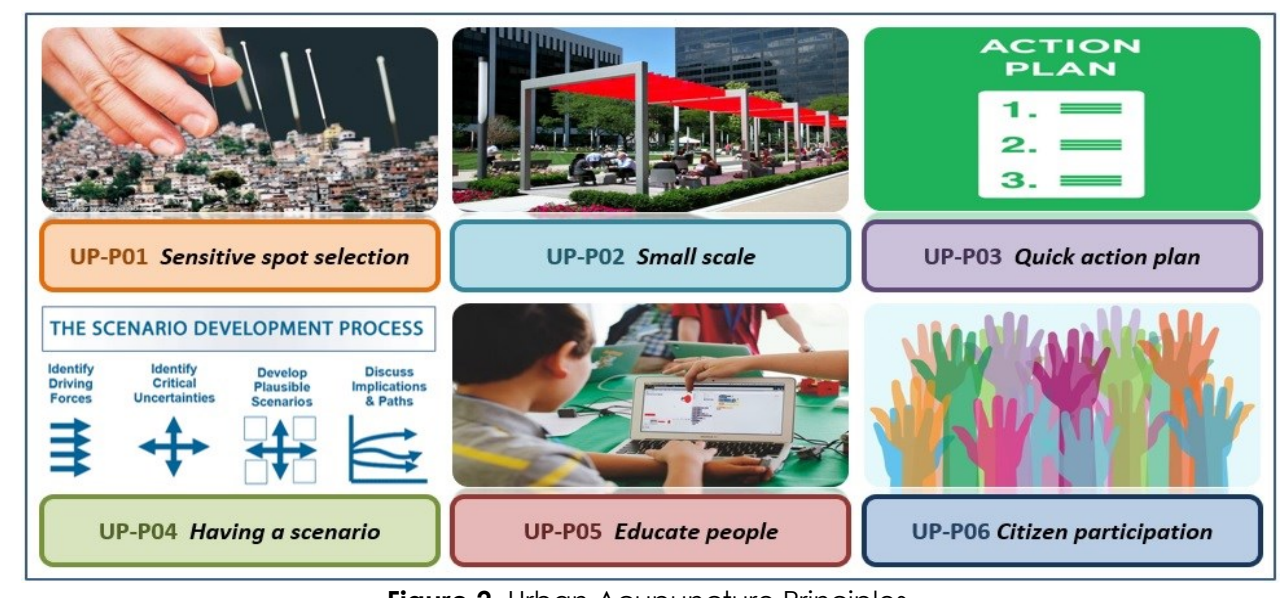

Figure 2. Urban Acupuncture Principles. 


\subsubsection{Sensitive spot selection (UP-P01)}

Like in Chinese acupuncture therapy, locating the sensitive points in the human body is the first and most important step for treatment. This principle was first stated by De Solà-Morales in his book, A matter of things (De Solà-Morales, 2008). On the other hand, Lerner defines the sensitive point in the urban tissue as the place that lacks energy flow in a sick city (Lerner, 2016).

\subsubsection{Small scale (UP-P02)}

Every UA intervention must be applied to smallscale spaces, as this approach aims for a big impact with small pilot projects. De SolàMorales mentioned that the scale is relative, and it does not only mean scale in size; it can also be applied to financial input or investment (De Solà-Morales, 2008).

\subsubsection{Quick action plan (UP-P03)}

While normal planning might take a while to design and implement, UA needs a quick action plan; Lerner refers to this as having a spark in our spaces and confirms that we don't have unlimited time to keep on planning and implementing (Lerner, 2016).

\subsubsection{Having a scenario (UP-P04)}

Lerner was the first to claim the necessity of having a scenario in any urban acupuncture development. He stated that every city development project would take three years to achieve, and to make it happen we would need to have a certain scenario with a design proposal and ideas (Lerner, 2016).

\subsubsection{Educate people (UP-P05)}

Like in placemaking, it is essential in the UA approach to understanding how the built environment has been received by its society. The people's knowledge and understanding of urban intervention accelerate the possibility of success (Nurdiansyah, 2018).

\subsubsection{Citizen participation (UP-P06)}

The decision-makers are not the only sources of design proposal-the people themselves take the lead in the UA approach. Citizen participation will lead the planner to a whole new vision of development, as the planner does not have the right answers for every problem (Stupar \& Savcic, 2009).

\subsection{Principles (UA-P) vs Strategies (UA-S)}

Though the UA principles mentioned above are a must for every project, each principle can be achieved through many strategies. Hence, principles are mandatory to be accomplished, while strategies are different according to each location's potential. Figure 3 describes how each principle can be accomplished through two or more strategies.

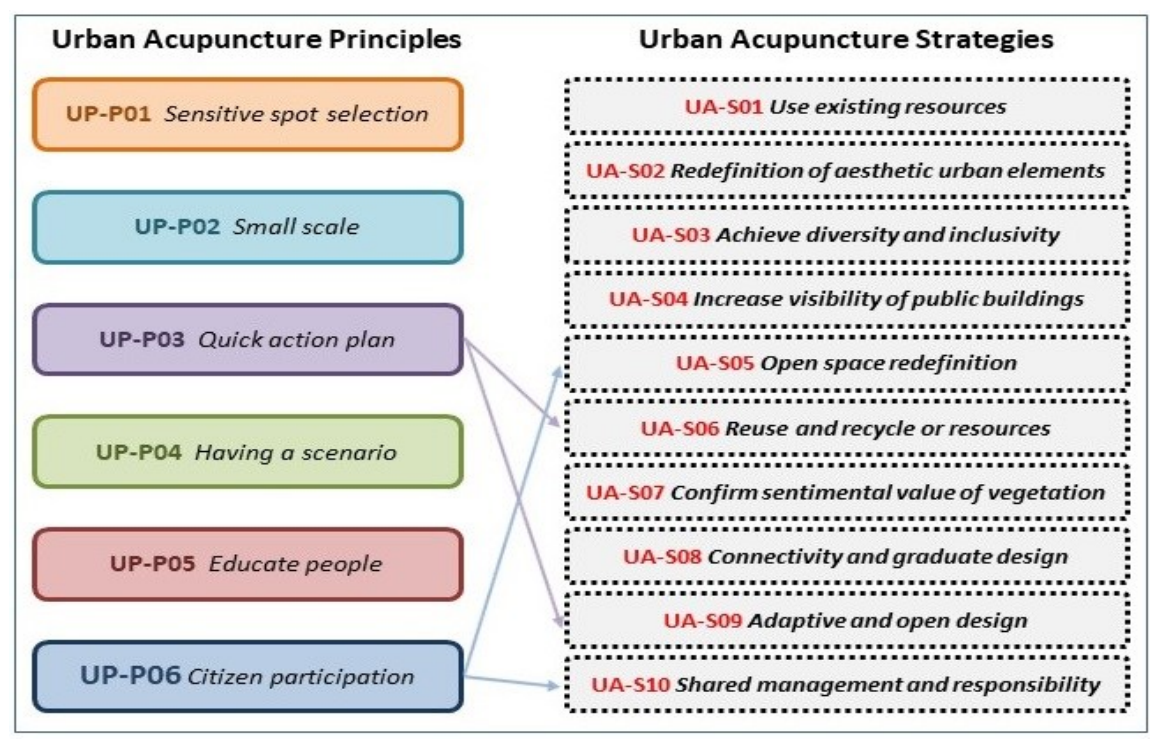

Figure 3. Urban Acupuncture Principles vs Strategies.

\section{Urban Acupuncture International Examples}

In this section, the paper introduces two successful projects that have applied the principles of UA. These selected projects will be presented and evaluated according to the different strategies mentioned earlier. Table 3 shows the selected case studies, their locations, and years of implementation. 
Table 3. Locations of selected international examples of Urban Acupuncture.

\begin{tabular}{l|l|l|l|l}
\hline No. & Year & Project name & Location & Level of Acupuncture \\
\hline 1 & 2016 & Upgrading of a slum area in Kampung & Jakarta, Indonesia & Buildings and Space \\
\hline 2 & 2015 & Pedestrian Passage in Downtown Cairo & Cairo, Egypt & Street \\
\hline
\end{tabular}

\subsection{Upgrading of a slum area in Kampung, Indonesia}

Jakarta has had massive expansion that has led to urban slum problems, especially in urban Kampung (Nurdiansyah, 2018). Kampung is largely inhabited by poor people who are mainly migrants, lacking work skills and who are in dire need of affordable housing (Harjoko, $2009 \mathrm{~b})$. The government had, therefore, to respond to this demand by offering affordable housing and urban spaces (Harjoko, 2009a). Table 4 shows the project information and location.

Table 4. Kampung Neighbourhood Upgrading project.

\section{Project Information}

$\begin{array}{lc}\begin{array}{l}\text { Type } \\ \text { project } \\ \text { Project } \\ \text { scale }\end{array} & \text { Affordable housing project } \\ & \text { Buildings and Space } \\ \begin{array}{l}\text { Main } \\ \text { concept }\end{array} & \begin{array}{l}\text { To create affordable housing buildings with } \\ \text { surrounding urban green spaces }\end{array}\end{array}$

\section{Project Description}

- The implementation of the upgrading project was finished by the government of Jakarta in 2016.

- Some of the poor residents (beneficiaries) in the area have been moved to the newly designed area.

- The project succeeded in improving the quality of housing in the neighbourhood.

- The area became healthier and cleaner from the improved quality of living and green areas.

- The level of participation and responsibility of the individual residents increased a lot during and after the project implementation.

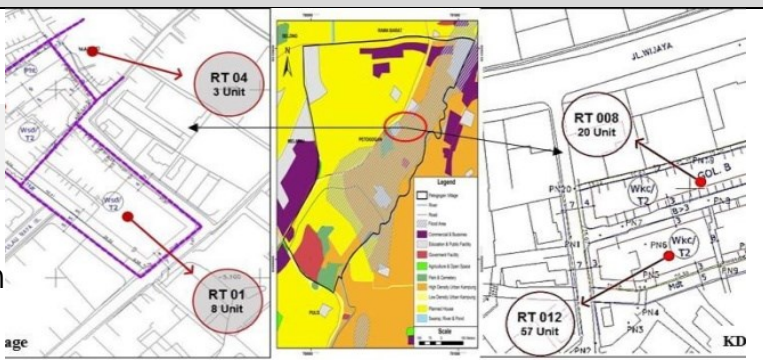

(Nurdiansyah, 2018)

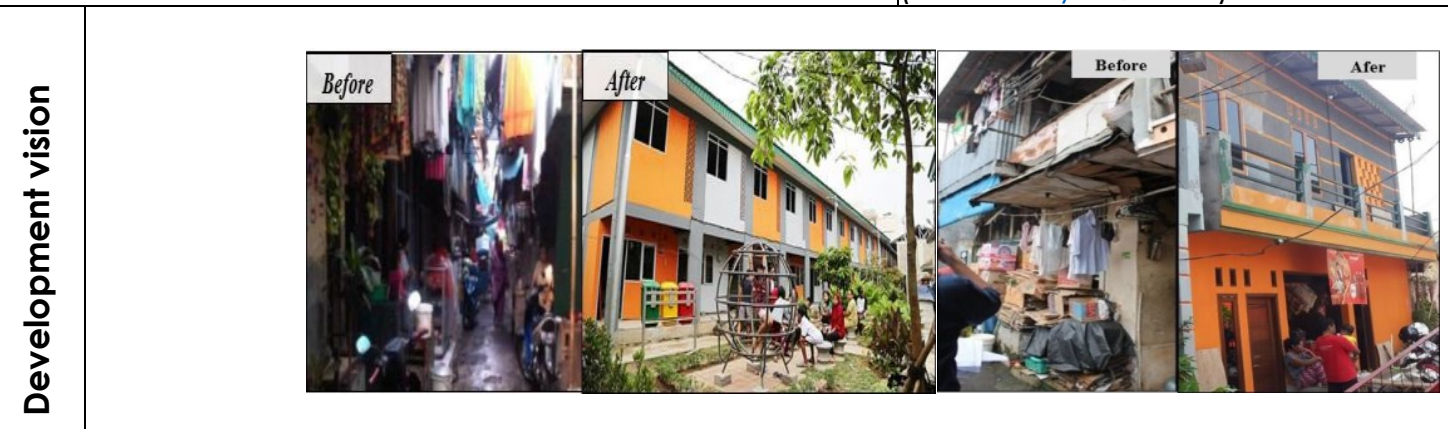




\subsection{Pedestrian Passage in Downtown Cairo, Egypt}

Downtown Cairo has been the city's centre of attention since 1992. There had been many trials for preserving its historic buildings and developing the open space network (Nassar, 2015b; Kamel et al., 2017). Most of the previous efforts, both academic and governmental, were related to documenting historical heritage (Elsorady, 2018). Recently, the private company, Al Ismailia for Real Estate Investment, attempted to develop the area by preserving its heritage buildings and creating dynamic urban fabric through small interventions in certain spots (Tang et al., 2015). According to Nassar, most people were using spaces in Downtown Cairo for social and cultural events by day and social gatherings by night (Nassar, 2014a). Later, after the 2011 revolution, it was notable, not only in Downtown Cairo, but across all the city that people had started to gather and socialise in many physical forms in the streets and spaces, engaging in many types of activities, like street performance, festivals, art fairs, and graffiti (Tang et al., 2015). The selected Passage in Downtown Cairo is one of the important destinations for small-scale gatherings because of its central location and variety of adjacent services. In this context, the Kodak Pedestrian passage between buildings was carried out by CLUSTER as a pilot project to engage the local community after it had been isolated for many years (CLUSTER, 2015).

Table 5. Pedestrian streetscape passage in Downtown Cairo.

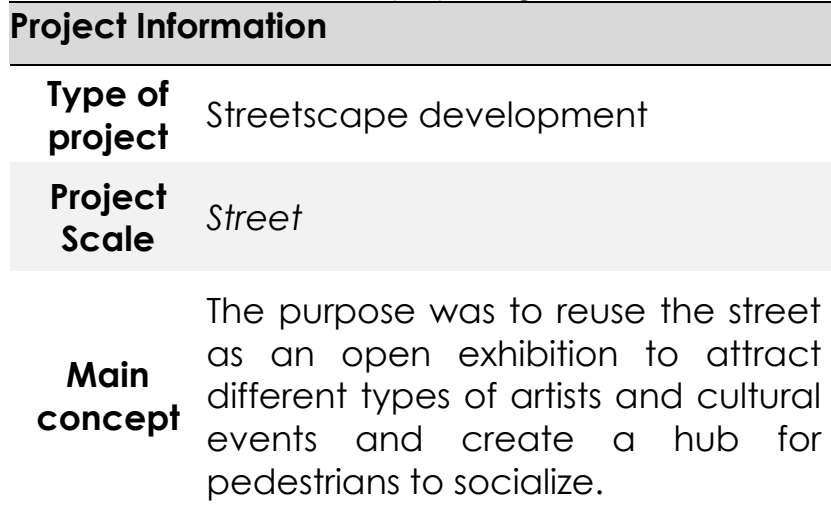

\section{Project Description}

The development project of the downtown passage mission aimed to achieve four main aspects:

- Establish a suitable platform for culture, integrating outdoor art and green areas.

- Create a network hub that would attract different stakeholders to participate with the local community.

- Make open space more accessible and create a more suitable environment for diverse activities.

- Use a variety of approaches to power the informal practices to create a more intimate space with the participation and management of inhabitants.

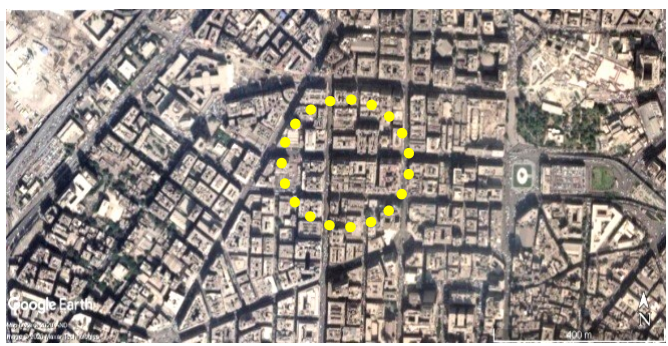

Site Location in Downtown Cairo

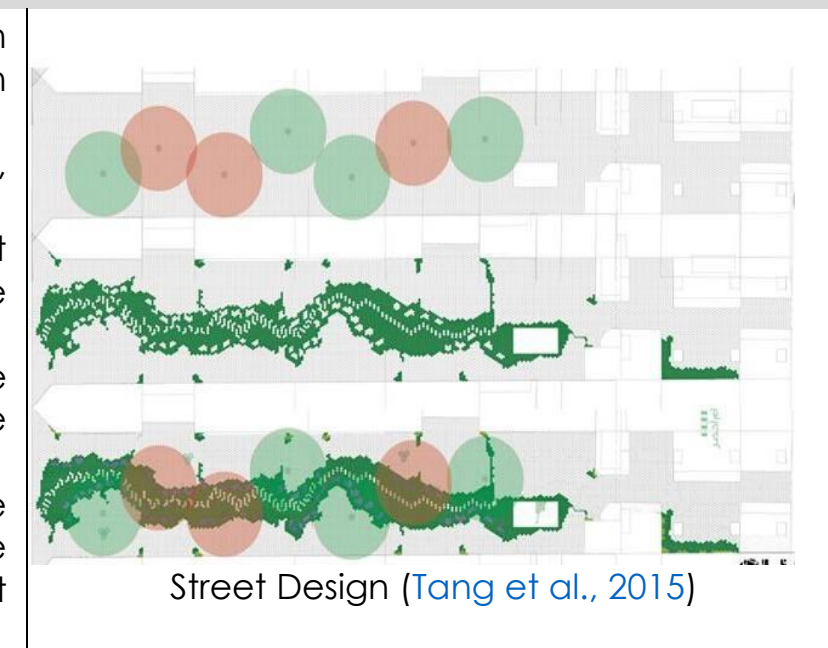




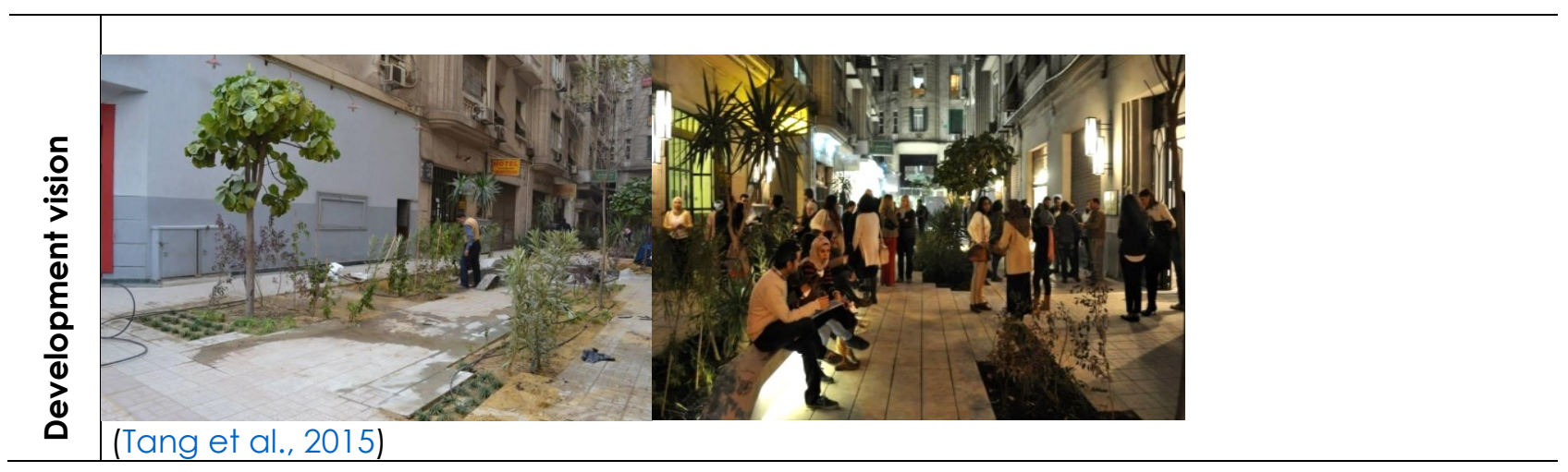

\subsection{Summary of international examples}

The results of analysing the two international examples of UA are presented in Table 6. The main conclusions can be listed as:

- The project in Cairo successfully applied most of UA strategies, which supported the success of the pilot project and allowed it to become a gathering hub for different types of users.

- The different scales of the two projects illustrate that the smaller the project was, the easier it was to apply more strategies and engage the local community more in the design and management processes.

Table 6. UA strategies in international examples.

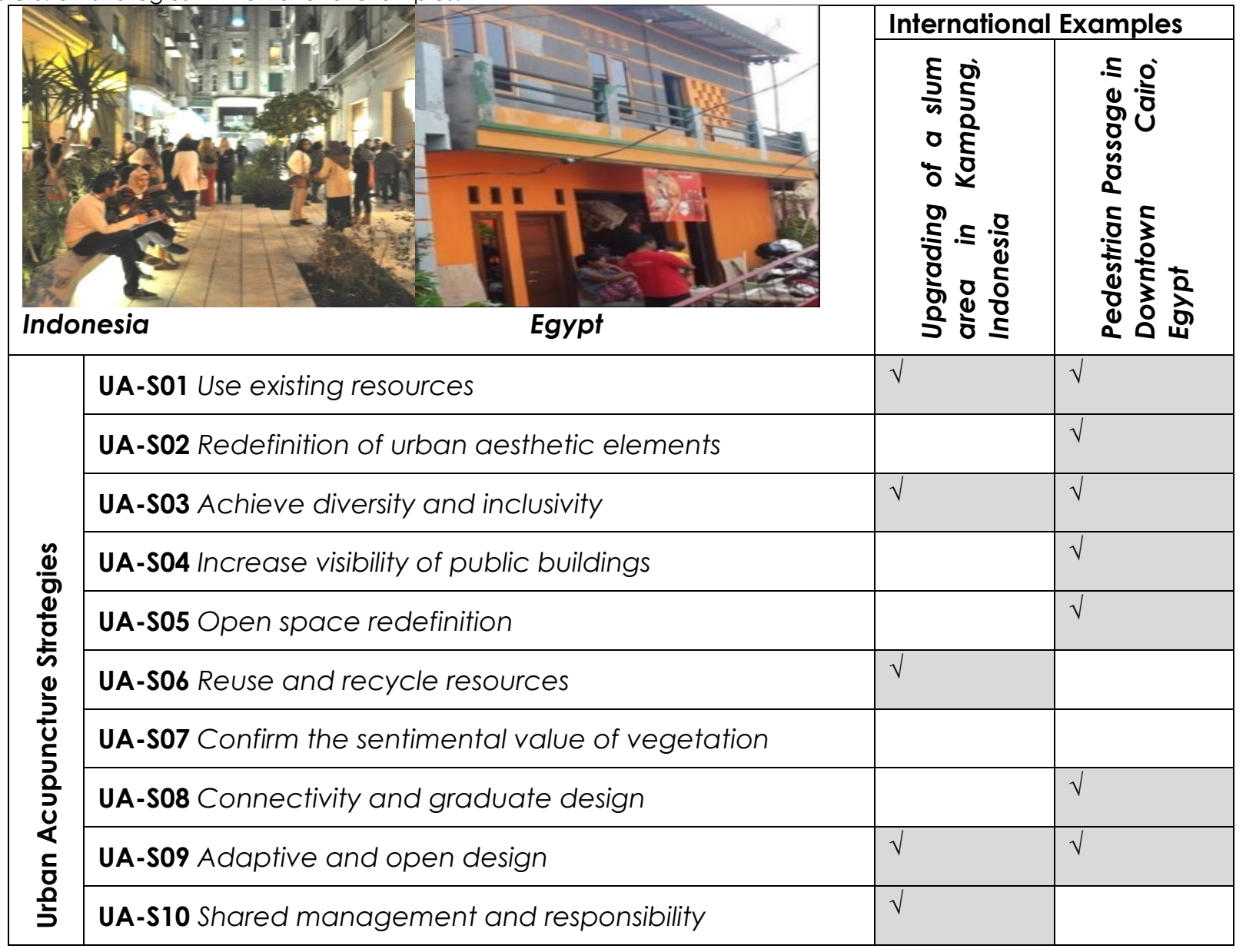




\section{Case Study of Riyadh City}

Riyadh city is the capital of KSA. It started as a small gated city and developed rapidly into a liveable metropolitan city over the years. This massive change happened during the period of the oil boom (1970-1990). Its rapid from a pedestrian-friendly environment into a caroriented city was not an easy evolution but a dramatic change full of conflicts and urban problems along the way (Menoret, 2014). Figure 4 shows the location of the city.

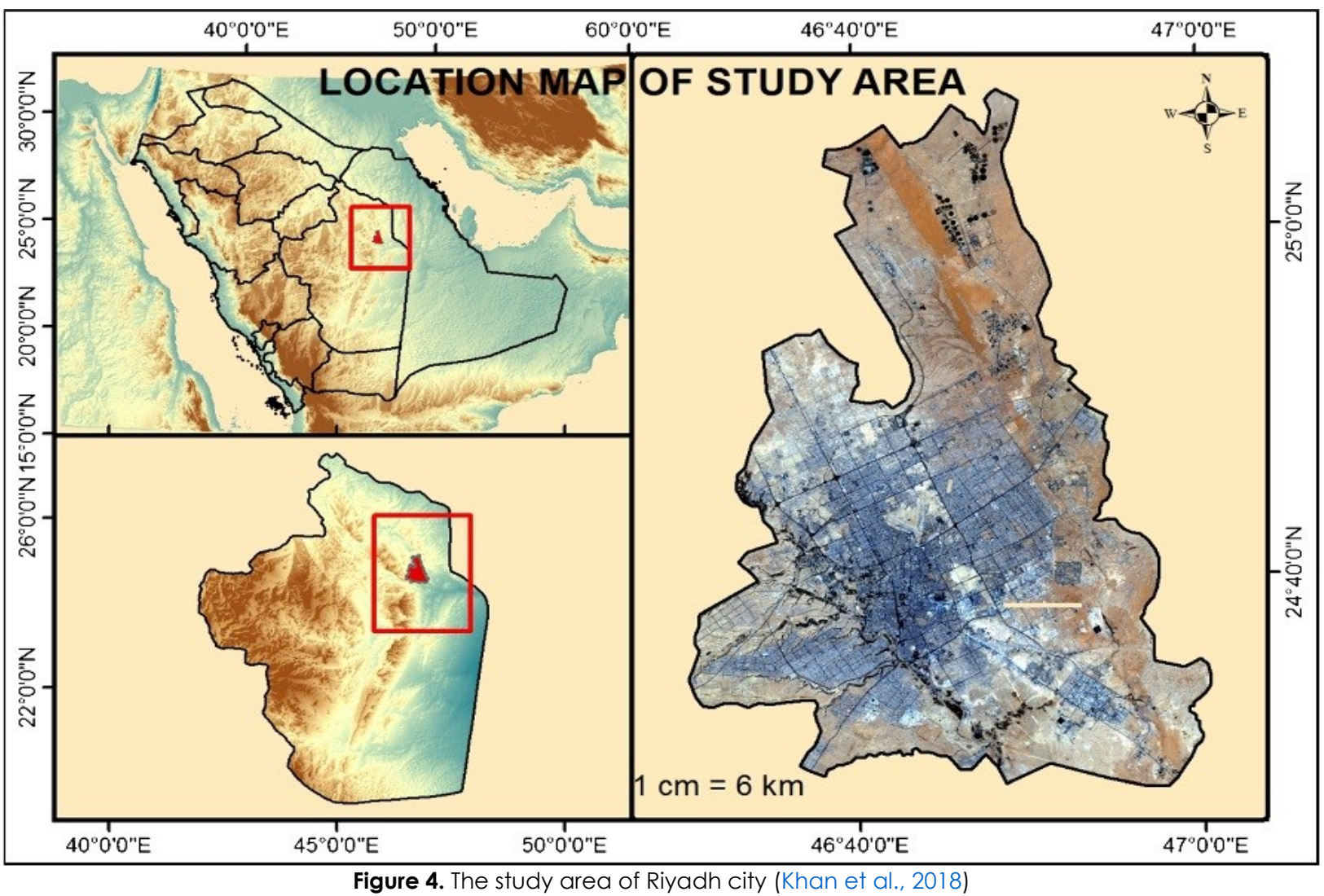

\subsection{Historical background and land use transformation}

The city of Riyadh is a centre of vibrant urban activity in the KSA, working as a link between the eastern and western metropolitan areas to form a crossing axis in the country (Al-Hemaidi, 2001). During the oil boom stage of development, the city was expanding at $8 \%$ per annum. The population surpassed one million by the 1980s, and the city covered almost $1600 \mathrm{~km}^{2}$ in 1986 (Mubarak, 2004). Today, the population has reached 6 million (Almahmood et al., 2018). Table 7 illustrates the two significant urban patterns developed in the city, which can be explained as follows:

- The old walled city, which is a traditional old community with narrow streets and high dependency on pedestrian movement (Almahmood et al., 2018).

- The grid street pattern, which has a new land use transformation of both housing types (Separated Villas) and larger road width and open space network accessed only by cars (Menoret, 2014). 
Table 7. Historical development of Riyadh.

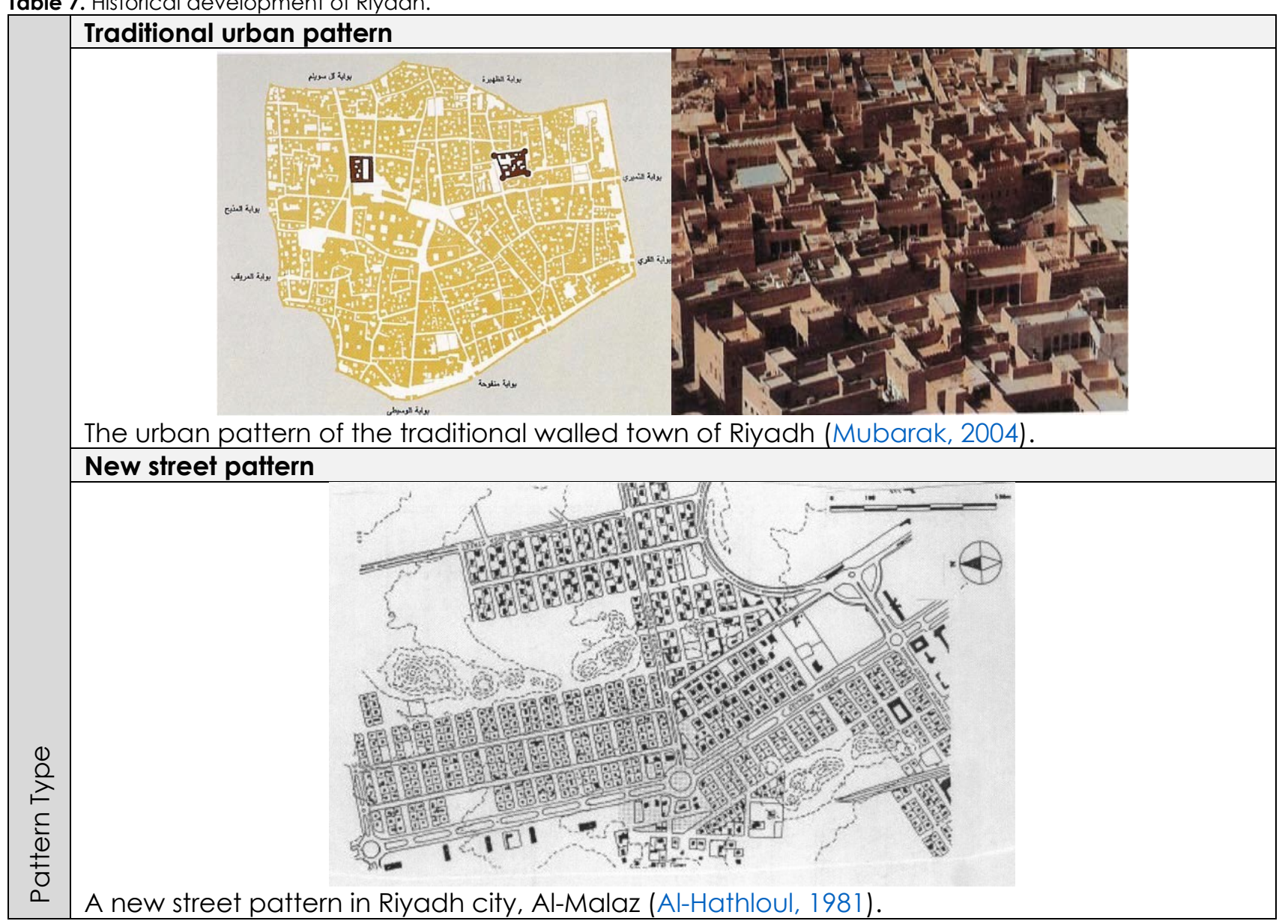

\subsection{Urban growth since 1972}

Most of the development plans made for the city adopted the car as the main mode of transportation. Hence, the street patterns for the city were designed in a hierarchical way, which included freeways and ring roads to connect all of the city with other regions in the kingdom, going low until reaching arterial streets that serve inside each neighbourhood (Al-Hathloul \& Mughol, 2004). Nowadays, the old traditional fabric of the city is in poor condition. Through the urban growth shown in Figure 5, there is a new network of roads that were laid out to facilitate car movement (Alotaibi \& Potoglou, 2018). Meanwhile, the spatial arrangement and the old open spaces network in traditional areas in Riyadh have been affected badly. Figure 5 illustrates the high rate of expansion for the city from 1972 to 2015, which will affect plans and creates an urgent need for public transport to connect the city.

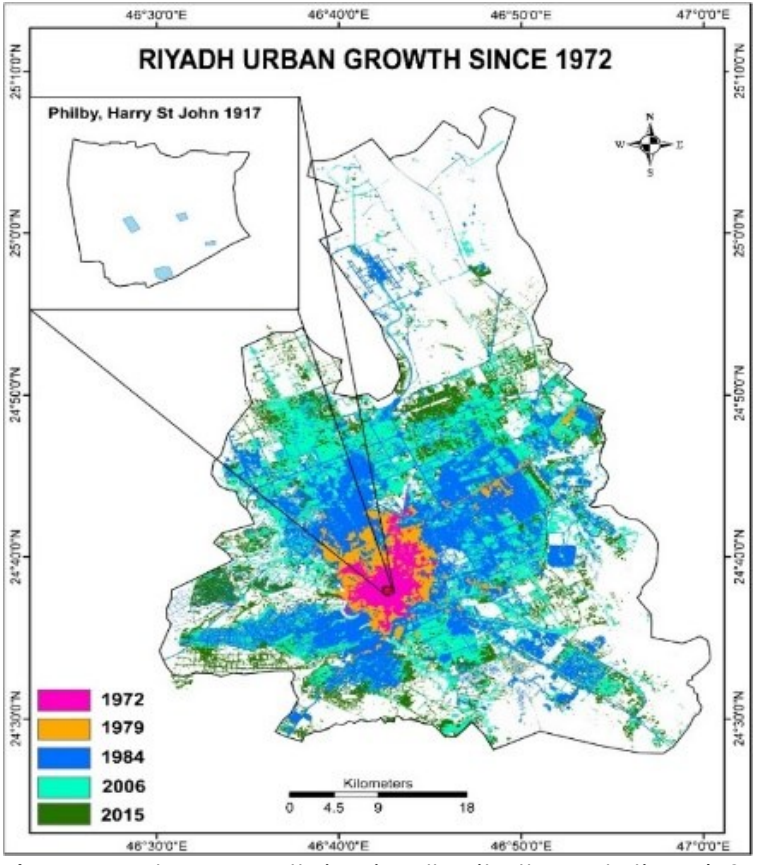

Figure 5. Urban growth in Riyadh city through time (19722015) (Khan et al., 2018) 


\subsection{Future Plans for Transportation}

As mentioned before, the city has developed rapidly and has highly become car-oriented (Al-Hathloul, 2017). It, however, lacks the public transportation system needed to connect its areas, which certainly affects pedestrian connectivity and consequently creates isolated spaces or green areas, either big or small (Aldalbahi \& Walker, 2016). Riyadh Development Authority developed a strategic development plan, Medstar (ADA, 2015), which identified some transport strategies in the city to include the following (Alotaibi \& Potoglou, 2018):

- Developing an effective public transport network in the city.

- Coordinating between high-density residential areas and major public transport spines.

- Developing the management measures of roads, including road charging and congestion pricing.

Figure 6 shows the designed metro lines in the city that connects all the urban areas.

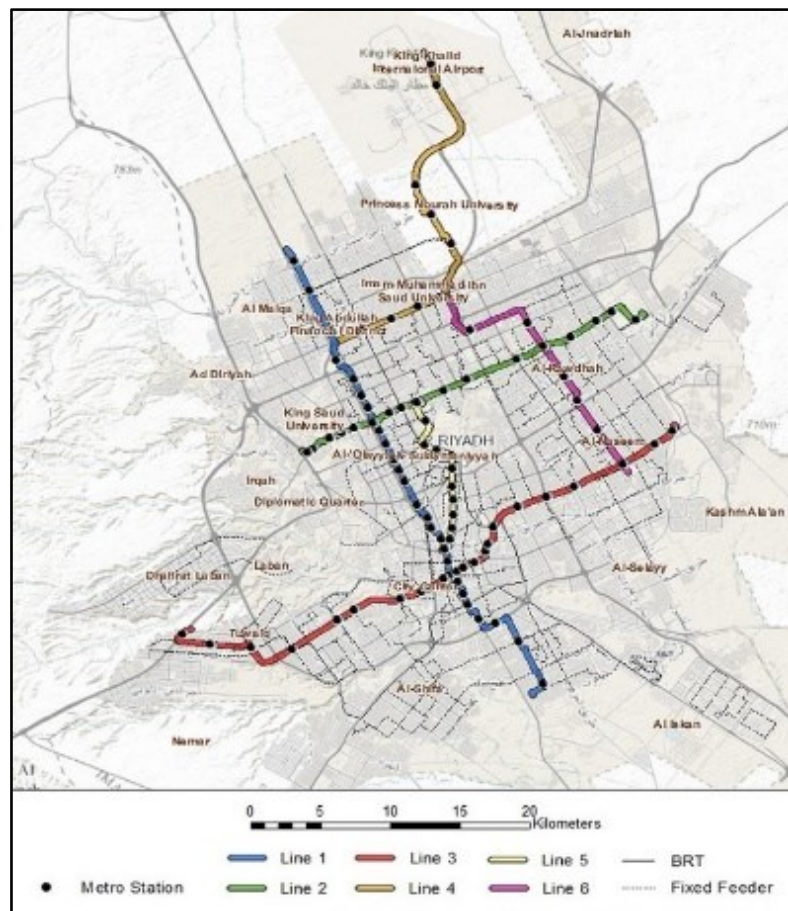

Figure 6. The planned public transport system in Riyadh Metro Line (ADA, 2015).

\subsection{Steps to select the right open space in Riyadh}

To this point in the current research, an overview of the Riyadh city master plan is undertaken. This progressively narrows to a smaller focus until the best sensitive spot where the concept of UA can be applied in the urban fabric is identified. This process will be staged in three steps as follows:

- The first step-Selecting the best development centre

- Second step-Urban catalyst and mixed-use areas

- The third step-Selecting the sensitive spot

\subsubsection{First step-Selecting the best} development centre

The Riyadh Public Transport Network (RPTN) consists of the metro lines network and the bus lines, which are meant to connect all the urban areas. These lines are already under implementation and were expected to be delivered in late 2019 (Al-Hathloul, 2017). This network adapted the concept of TransitOriented Development in the city, and for the research limitation, the historic centre will be selected to choose from it a suitable open and green space where the concept of UA can be applied. Figure 7 shows the planned five transitoriented development centres in Riyadh and the selected centre in the middle.

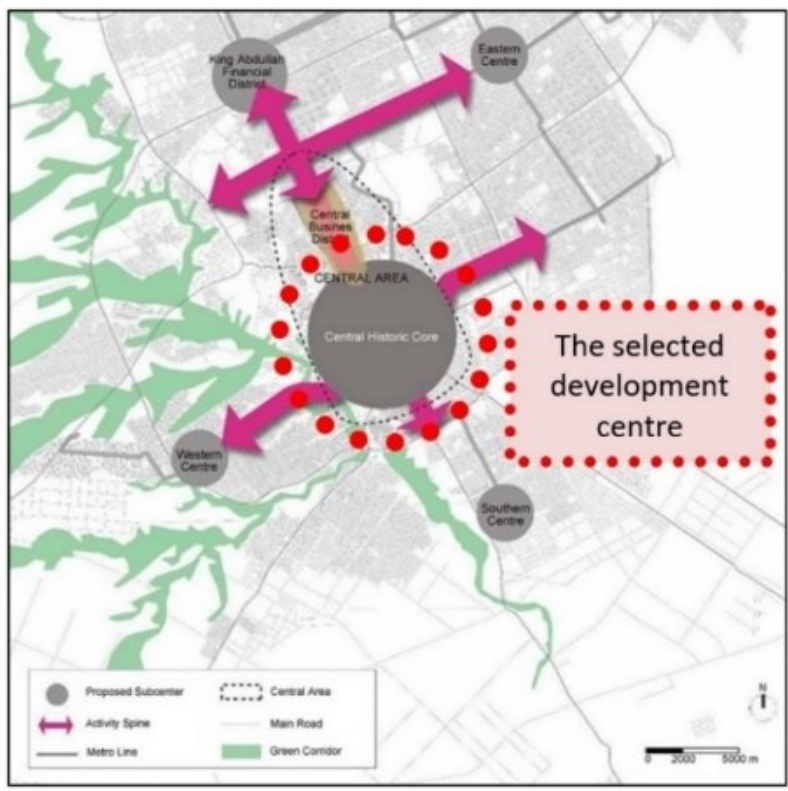

Figure 7. Transit-Oriented Development TOD strategy in the Riyadh metropolitan area (ADA, 2016).

\subsubsection{Second step-Urban Catalyst and mixed- use areas}

In this stage, the research navigates the land use in the selected historical centre, where four districts were selected randomly from highly mixed-use areas and evaluated to choose the most suitable one to study on an urban level. The best location to apply the UA approach will thereafter be picked. While Figure 8 illustrates 
the detailed land use of these districts with their population densities and development rates (ADA, 2017), Table 8, on the other hand, evaluates the four districts from the development centre to provide the basis for picking the best site.
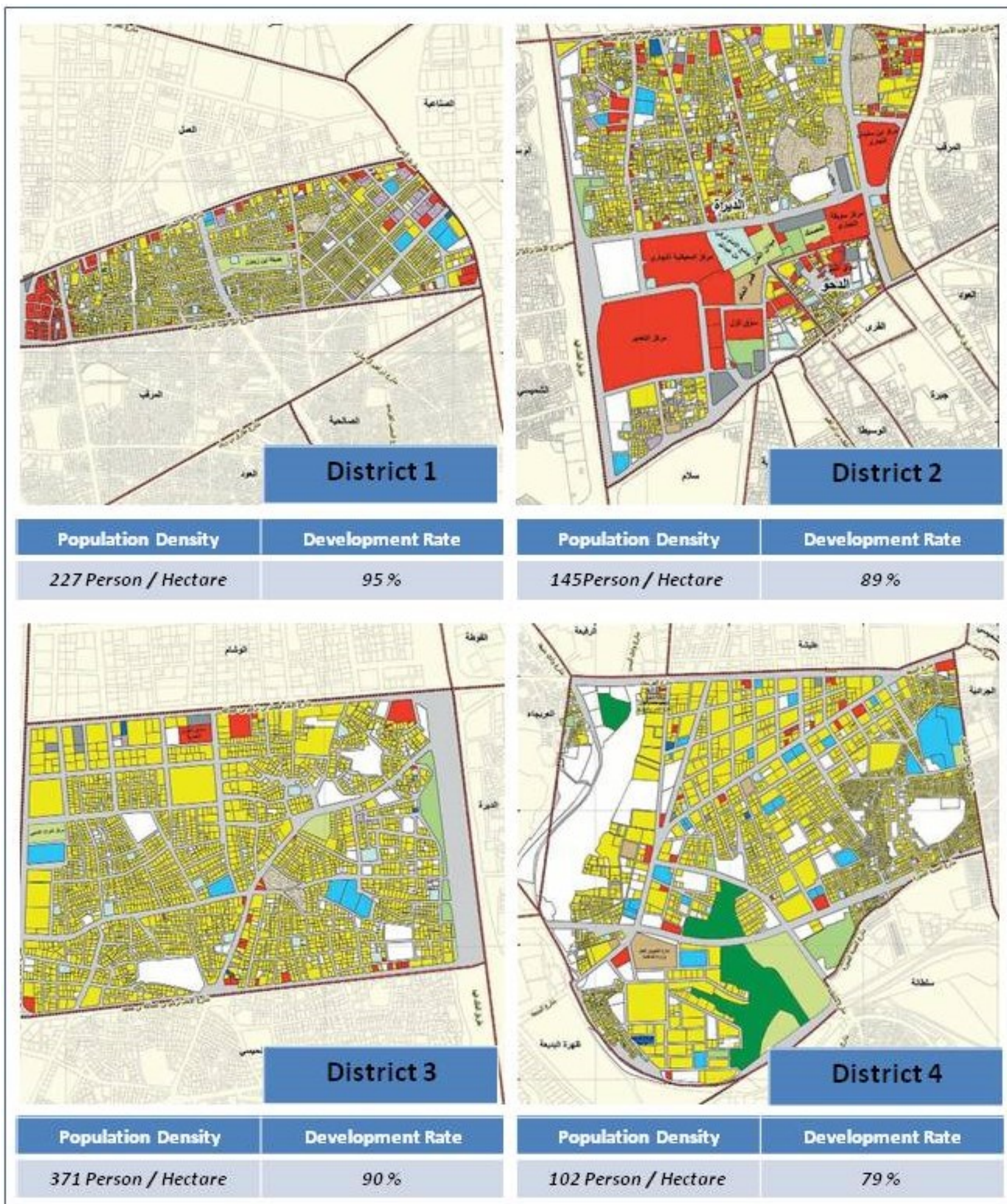

\begin{tabular}{|c|c|}
\hline Population Density & Development Rate \\
\hline 102 Person / Hectore & $79 \%$ \\
\hline
\end{tabular}

Figure 8. Detailed land use of some areas in the historical centre (ADA, 2017) 
Table 8. Evaluating the four districts to select the best one Selected Zones.

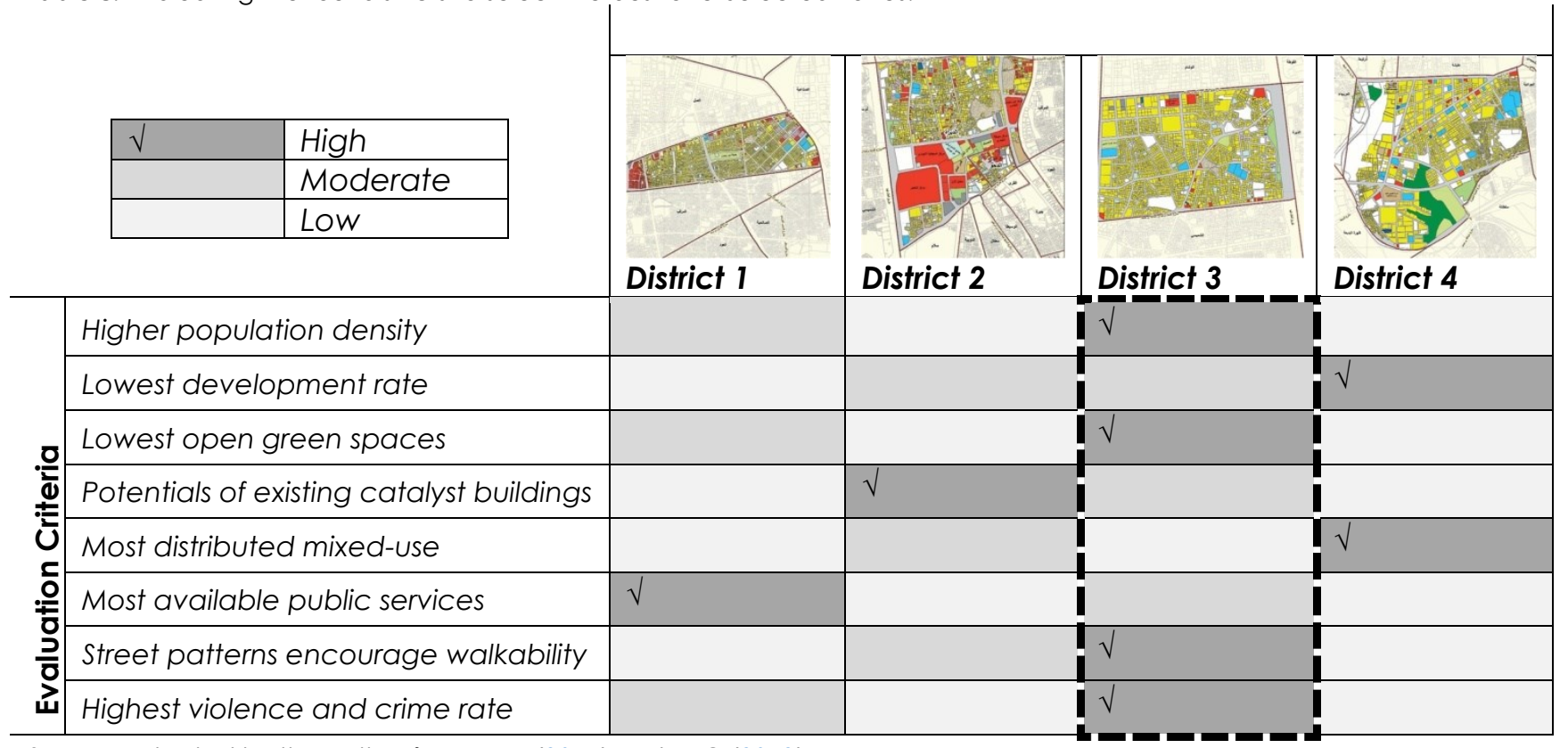

Source: Adapted by the author from ADA (2017) and RUO (2018).

As shown in the table above, the district that needs much development appears to be District 3, according to the criteria points which were derived from the literature review.

\subsubsection{Third step-Selecting the sensitive spot}

This stage focus on the selected district from where the appropriate space to develop will be chosen. The process will be performed according to the aspects presented in Table 2 highlighting the filters that should be used to choose the best human-centered open space. Figure 9 consequently shows the urban development pattern for District 3 which highlights the most sensitive spots that may be chosen to apply the concept of UA.

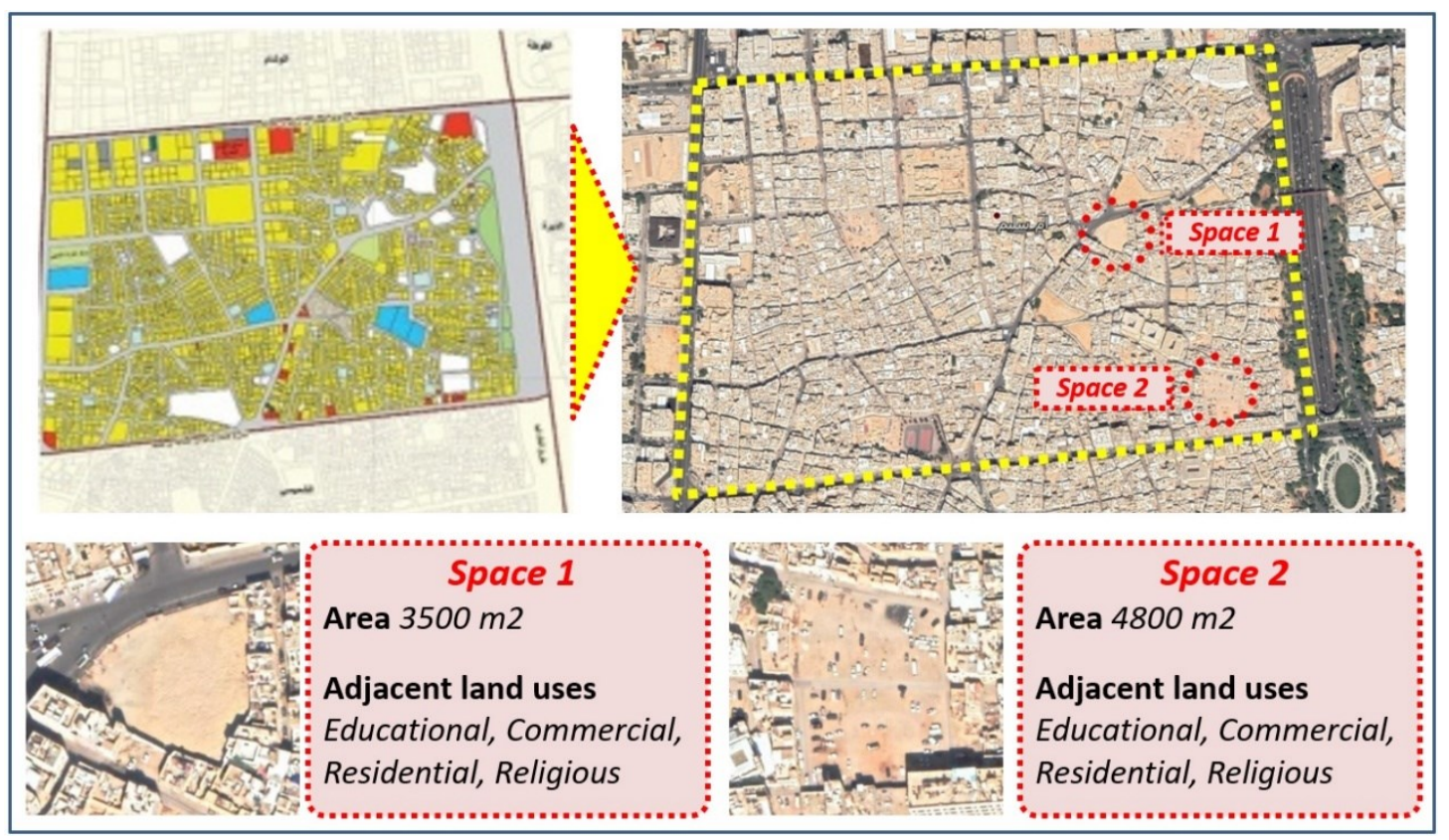

Figure 9. The urban street pattern for District 3 with the potential suitable sensitive spots to apply the UA concept. 


\section{Filtering framework to apply Urban Acupuncture Approach}

After undertaking a literature review on the UA that included its principles and strategies, this section now concludes the filtering framework that may be applied to Riyadh city or any other place to select a suitable site where UA as a concept may be applied. Figure 10 presents a conclusion on the five filters.

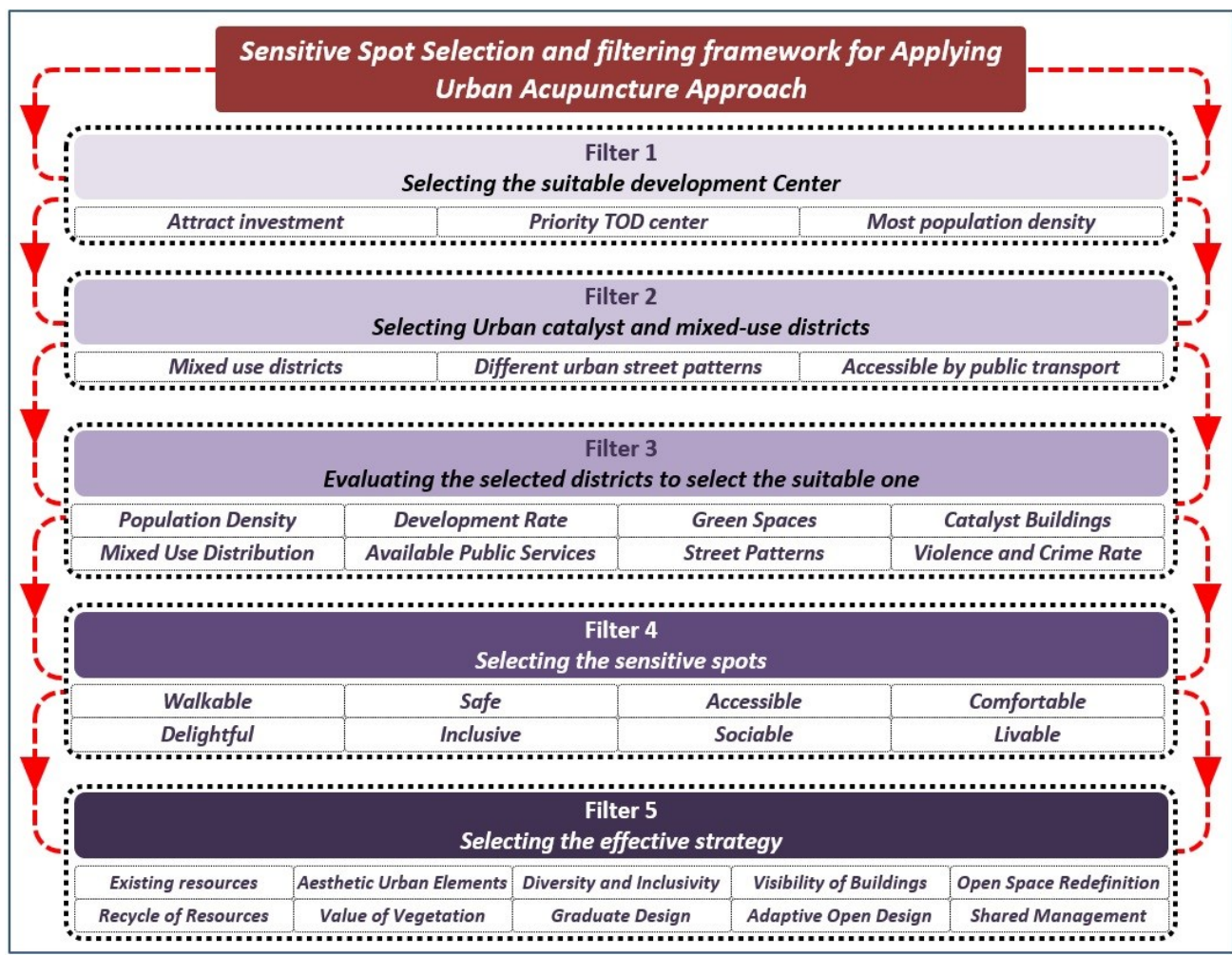

Figure 10. Sensitive spot selection and filtering framework for applying the UA approach.

\section{Conclusions and Recommendations}

This paper has examined the use of UA as an alternative tool for dealing with open spaces on a smaller scale. It also introduced the concept of evolutionary history and discussed how UA differs from other urban renewable strategies in addition to highlighting the applicable strategies and principles. The paper consequently examined the city of Riyadh as a case study for implementing UA and proposed a filtering selection framework that can be applied to select the suitable open spaces for adopting UA. The paper concludes that as a small-scale space approach and a progressive concentrated urban renewal strategy, UA enhances a city's potential rather than entirely relying on the urban planners' vision. In this way, the city's development remains healthier, effective, and sustainable. The selected international case studies further showed that the UA could be more effective on smallerscale action projects where it can achieve a tremendous effect in a noticeably short time since it remains very flexible by encouraging ongoing planning and implementation. The research further concludes that the principles of UA should be examined in future studies with a focus on more practical research being undertaken in different locations by engaging all stakeholders in the development process.

As a recommendation, since the city of Riyadh shows the highest rate of urban expansion, there is a need to adopt the strategic urban development plans and localise small-scale space interactions to create a balance between the newly planned district and the old ones through UA. It is moreover important to change the existing social and cultural norms by frequently engaging the people through awareness in creating a better environment as one of the important principles of UA. Finally, since the city of Riyadh has a mixture of newly planned and large old historical fabric, a different development approach should be adopted for each of the two regarding the urban fabric and sociocultural composition of the residents. 
Finally, considering the world is going through the COVID-19 pandemic and that most of the affected districts have the highest population density with no green lung or development projects, the concept of green roofs in buildings can, therefore, be a good approach to deal with the high-density district in Riyadh. This can be revitalized by selecting suitable spots that may be developed on a separate case-by-case basis.

\section{References}

Abderrahman, W. A. (2000). Urban Water Management In Developing Arid Countries. Water Resour Dev, 16(1),

7-20. https://doi.org/10.1080/07900620048536

ADA (Arriyadh Development Authority). (2015). Updated Master Plans for Northern and Eastern Suburbs, The Royal Commission For Riyadh City: Saudi Arabia. Retrieved January 12, 2020. https://www.rcrc.gov.sa/en/studies

ADA (Arriyadh Development Authority). (2016). Transit Oriented Development, Strategy \& Case Studies for Riyadh. The Royal Commission For Riyadh City: Saudi Arabia. Retrieved January 12, 2020. https://www.rcrc.gov.sa/en/studies

ADA (Arriyadh Development Authority). (2017). Land Use Atlas for Riyadh. The Royal Commission For Riyadh City: Saudi Arabia. Retrieved January 12, 2020. https://www.rcrc.gov.sa/en/studies

Aldalbahi, M., \& Walker, G. (2016). Riyadh transportation history and developing vision. Procedia - Social and Behavioural Sciences, 216, 163-171.

https://doi.org/10.1016/j.sbspro.2015.12.024

Al-Hathloul, S. (1981). Tradition, Continuity and Change in the Physical Environment: The ArabMuslim City, Ph.D. Thesis, MIT University, USA. https://dspace.mit.edu/handle/1721.1/46401

Al-Hathloul, S. (2017). Riyadh Development Plans in the Past Fifty Years (1967-2016). Current Urban Studies, $\quad 5(1), \quad$ 97-120. https://doi.org/10.4236/cus.2017.51007

Al-Hathloul, S., \& Mughol, M. A. (2004). Urban growth management, the Saudi experience. Habitat International, 28(4), 609-623. https://doi.org/10.1016/j.habitatint.2003.10.009

Al-Hemaidi, W. (2001). The metamorphosis of the urban fabric in an Arab-Muslim City: Riyadh, Saudi Arabia. Journal of Housing and the Built Environment, 16(2), 179-201. https://doi.org/10.1023/A:1017908616597

\section{Acknowledgements}

This research did not receive any specific grant from funding agencies in the public, commercial, or not-for-profit sectors.

\section{Conflict of interests}

The author declares no conflict of interest.

Almahmood, M., Gulsrud, N., Schulze, O., Carstensen, T., \& Jørgensen, G. (2018). Human-centred public urban space: exploring how the 're-humanisation' of cities as a universal concept has been adopted and is experienced within the socio-cultural context of Riyadh. Urban Research \& Practice, 1-24. https://doi.org/10.1080/17535069.2018.1539512

Alotaibi, O., \& Potoglou, D. (2018). Introducing public transport and relevant strategies in Riyadh City, Saudi Arabia: a stakeholders' perspective. Urban, Planning and Transport Research, 6(1), 35-53. https://doi.org/10.1080/21650020.2018.1463867

Apostolou, M. (2015). Urban eco-acupuncture methods: case study in the city of Athens. 2nd International Conference on Changing Cities II: Spatial, Design, Landscape \& Socio-economic Dimensions. Porto Heli, Greece. 932-940.

Carmona, M., Tiesdell, S., Heath, T. \& Oc, T. (2010). Public Places Urban Spaces, the Dimensions of Urban Design. 2nd ed. Routledge.

Casagrande, M. (2020). From Urban Acupuncture to the Third Generation City. In: Roggema R. (eds) Nature Driven Urbanism. Contemporary Urban Design Thinking. Cham, Springer. https://doi.org/10.1007/978-3-030-26717-9 7

CLUSTER. (2015). Cairo Laboratory for Urban Studies, Training and Environmental Research. Curry Stone Foundation, Egypt.

De Meulder, André Loeckx, Kelly Shannon, Rafael Tuts \& Han Verschure. (2004). A Project of Projects. Urban Trialogues, localising agenda 21, UN-HabitatPGCHS, University of Leuven, Nairobi.

De Solà-Morales, M. (2008). A Matter of Things. Rotterdam, NAi Publishers.

Degen, M., \& Garcia, M. (2012). The Transformation of the 'Barcelona Model': An Analysis of Culture, Urban Regeneration and Governance. International Journal of Urban and Regional Research,36(5), 
1022-1038. 2427.2012.01152.x

Ellin, N. (2007). Postmodern urbanism. New York: Princeton Architectural Press.

Elsorady, D. (2018). Revitalisation of Downtown Khedive Cairo: A contested sovereignty. Cities, 73(1), 51-62.

https://doi.org/10.1016/j.cities.2017.10.009

Ewing, R., \& Handy, S. (2009). Measuring the unmeasurable: Urban design qualities related to walkability. Journal of Urban Design, 14 (1), 65-84. https://doi.org/10.1080/13574800802451155

Gehl, J., \& Lars, G., (2008). New City Spaces. Copenhagen, Danish Architectural Press.

Harjoko, Y. (2009a), Urban Kampung: Its Genesis and Transformation into Metropolis, with particular reference to Penggilingn, Jakarta. Saarbrücken, VDM Verlag Dr. Müller.

Harjoko, Y. (2009b). Urban Acupuncture: An Alternative, Purposive intervention to urban development to generate sustainable positive ripples for an 'Aided Self-Help' Kampung Improvement. Informal Settlements and Affordable Housing.

Houghton, K., Foth, M., \& Miller, E. (2015). Urban Acupuncture: Hybrid Social and Technological Practices for Hyperlocal Placemaking. Journal of Urban Technology, 22(3), 3-19. http://dx.doi.org/10.1080/10630732.2015.1040290

Jackson, T. (2018). What makes cross-cultural management scholarship critical? It depends on how we understand 'culture'. International Journal of Cross Cultural Management, 18(3), 267-270. https://doi.org/10.1177/1470595818816414

Jacobs, J. (2002). The death and life of great American cities. Random House.

Kamel, B., Wahba, S., Kandil, A., \& Fadda, N. (2017). Reclaiming Streets as Public Spaces for People: Promoting Pedestrianization Schemes in AlShawarbi Commercial Street - Downtown Cairo. 1st International Conference on Towards a Better Quality of Life, Technische Universität Berlin Campus El Gouna, Egypt.

http://dx.doi.org/10.2139/ssrn.3170365

Khan, M., Suhail, M., \& Alharbi, T. (2018). Evaluation of urban growth and land use transformation in Riyadh using Landsat satellite data. Arabian Journal of Geosciences, 11(18), 1-13. https://doi.org/10.1007/s12517-018-3896-5
Lastra, A., \& Pojani, D. (2018). Urban acupuncture' to alleviate stress in informal settlements in Mexico. Journal of Urban Design, 23(5), 749-762.

\section{https://doi.org/10.1080/13574809.2018.1429902}

Lerner, J. (2016). Urban Acupuncture: Celebrating Principles of Change That Enrich City Life. Island Press.

Madanipour, A. (2010). Marginal public spaces in European cities. Journal of Urban Design, 9(3), $267-$ 286. https://doi.org/10.1080/1357480042000283869

Marzi, M. \& Ancona, N. (2004). Urban acupuncture, renewal of a Milan's urban ring road. ISoCaRP. Retrieved December 15, 2019. http://www.isocarp.net/Data/case studies/553.pdf

Mehta, V. (2014). Evaluating public space. Journal of Urban Design 19 (1), 53-88. https://doi.org/10.1080/13574809.2013.854698

Menoret, P. (2014). Joyriding in Riyadh: Oil, Urbanism, and Road Revolt. Cambridge University Press. https://doi.org/10.1017/CBO9781139548946

Messeter, J. (2015). Social media use as urban acupuncture for empowering socially challenged communities. Journal of Urban Technology, 22(3), 79-96.

https://doi.org/10.1080/10630732.2015.1040291

Mubarak, F. (2004). Urban growth boundary policy and residential suburbanization: Riyadh, Saudi Arabia. Habitat International, 28(4), 567-591. https://doi.org/10.1016/j.habitatint.2003.10.010

Nassar, U. (2014a). Space and Politics: changing of social activities in Tahrir square, Egypt. In G. Rata, H. Arslan \& P. Runcan (Eds.), Interdisciplinary Perspectives on Social Sciences (pp. 189-198), Cambridge Scholars Publishing.

Nassar, U. (2014b). Social Network Programs and Redesign of Urban Places for Pedestrians - Study of Khedivial Cairo Downtown. International Conference on Social Sciences and Humanities SOCIOINT ' 14, Istanbul, Turkey.

Nurdiansyah, A. (2018). Urban Slum Upgrading Policy in Jakarta (Case Study: Kampung Deret Program Implementation). The Indonesian Journal of Planning and Development, 3(1), 19-31. https://doi.org/10.14710/ijpd.3.1.19-31

Palgrave, W. (1868). Personal narrative of a year's journey through Central and Eastern Arabia (186263). Macmillan. 
Permentier, M. et al. (2013). Work on the neighbourhood: a quasi-experimental evaluation of the strength neighbourhood policy [Werk aan de wijk, een quasi-experimentele evaluatie van het krachtwijkenbeleid]. Den Haag: Sociaal en Cultureel Planbureau.

Carlos Rosa-Jiménez, Nuria Nebot, Alberto García Moreno and María José Márquez Ballesteros. (2017). Near Zero Consumption Building as an Urban Acupuncture for a Vertical Slum. A Case Study in the City of Malaga, Spain. IOP Conf: IOP Conference Series: Materials Science and Engineering, 245, 052028. $\underline{899 X / 245 / 5 / 052028}$

RUO (Riyadh Urban Observatory) (2018). Urban Indicators for Riyadh. Retrieved January 15, 2020. http://www.ruo.gov.sa/EN/

Shidan, C. \& Qian, S. (2011). "Urban Acupuncture" Strategy in the Urban Renewal. 2011 International Conference on Electric Technology and Civil
Engineering (ICETCE), Lushan, China. https://doi.org/10.1109/ICETCE.2011.5774234

Stupar, A., \& Savcic, V. (2009). The New Urban Acupuncture: Intermodal Nodes between Theory and Practice. Proceedings REAL CORP, April 2009, Tagungsband.

Tang, Y., Chen, L., Sun, Y., Shen, L., \& Abdel-Ghani, T. (2015). Urban Acupuncture and its Practices in China \& Egypt. Creative Urban Renewal, WS 2015/16, Advanced Urbanism, Institute for European Urban Studies, BAUHAUS-University Weimar.

Varna, G. (2014). Measuring Public Space: The Star Model (Design and the Built Environment), Routledge.

Wolfe, C. R., (2011). Urbanism Without Effort: Reconnecting with First Principles of the City. Island Press. https://doi.org/10.5822/978-1-61091-962-3 